\title{
Biohydrogen Production by Anaerobic Fermentation of Sewage Sludge - Effect of Initial pH
}

\author{
Ilknur Senturk ${ }^{1, *}$, Hanife Buyukgungor ${ }^{2}$ \\ ${ }^{1}$ Environmental Engineering Department, Engineering Faculty, Cumhuriyet University, Turkey \\ ${ }^{2}$ Environmental Engineering Department, Engineering Faculty, Ondokuz Mayis University, Turkey
}

Copyright $\bigcirc 2017$ by authors, all rights reserved. Authors agree that this article remains permanently open access under the terms of the Creative Commons Attribution License 4.0 International License

\begin{abstract}
The aim of this study is to investigate the usability of sewage sludge, a waste from waste water treatment facility, at constant temperature and different $\mathrm{pH}$ conditions in the hydrogen production by dark fermentation. It was understood from the results that hydrogen production varies according to the characterization of activated sludge. In the experiments performed at different $\mathrm{pH}$ values $\mathrm{pH}$ $4-8)$ at $35^{\circ} \mathrm{C}$, maximum hydrogen production was achieved within the first 24 hours. Except for one performed at $\mathrm{pH} 8$, hydrogen gas release was observed at other $\mathrm{pH}$ values within 2 hours. However, according to the results obtained at the 24th hour, maximum hydrogen production (2489 $\mathrm{mL} / \mathrm{m}^{3} \mathrm{H}_{2}$ ) was observed at $\mathrm{pH} 8$.
\end{abstract}

Keywords Biohydrogen Production, Dark Fermentation, Mixed Microflora Inoculum, Renewable Energy Sources, Sewage Sludge

\section{Introduction}

Hydrogen is known as a clean renewable energy source. Combustion of hydrogen produces no greenhouse gases, and has a high-energy yield of $142.35 \mathrm{~kJ} \mathrm{~g}^{-1}$, which is 2.75 -fold greater than that of hydrocarbon fuels $[1,2]$. Currently, hydrogen has been widely recognized as an ideal alternative source of energy to substitute fossil fuels, as it is renewable and zero-pollutant-emission energy [3]. Hydrogen generation can be classified into two ways: chemical-physical and biological methods. The chemical-physical methods are energy intensive and expensive. In contrast, the biological methods are environmentally favorable and consume less energy [1].

Sewage sludge from a wastewater treatment plant is rich in carbohydrates and proteins and thus it is a potential substrate for producing hydrogen [3-5]. Several publications have reported that hydrogen can be biologically produced by anaerobic dark fermentation of sludge [6]. Using sewage sludge as the substrate for fermentative hydrogen production offers several advantages over the use of other biomass sources. It is available at little or no cost [7]. The prime advantage is expensive management and disposal of sewage sludge can be surmounted. The amount required for disposal can be converted into a credit against the cost of hydrogen production [8].

Anaerobic digestion is an appropriate technique for reduction in the volume and weight of excess sludge before final disposal, and it is employed worldwide as the oldest and most important process for sludge stabilization. Hydrogen is an intermediary metabolite of anaerobic digestion, which is rapidly taken up and converted to other products by the hydrogen consuming microorganisms in the third stage of anaerobic digestion [9].

In this study, it is expected to address the problems associated with waste activated sludge disposal through simultaneous generation of clean gaseous energy in the form of hydrogen. A synchronous objective was to investigate the influence of different $\mathrm{pH}$ on the hydrogen production using waste sludge by anaerobic fermentation. Batch tests were carried out to analyze influence of the initial fermentation $\mathrm{pH}$ value on hydrogen production from sewage sludge at the stable temperature.

\section{Materials and Methods}

\subsection{Sewage Sludge}

Table 1. Mean characteristics of sewage sludge used in experiments

\begin{tabular}{|c|c|}
\hline Item & Value $(\mathbf{m g} / \mathbf{L})$ \\
\hline $\mathrm{pH}$ & $6-7$ \\
\hline T protein & 5500 \\
\hline S protein & 67.8 \\
\hline T carbohydrate & 2171.4 \\
\hline S carbohydrate & 8.4 \\
\hline T COD & 15440 \\
\hline S COD & 100 \\
\hline Total solid (TS) & 17785 \\
\hline Volatile solid (VS) & 12322 \\
\hline
\end{tabular}


Sewage sludge used in the study was obtained from return sludge pumping station of the secondary sedimentation tank of a biological municipal wastewater treatment plant located in Samsun, Turkey and its characteristics are shown in Table 1. The sludge was first concentrated by settling at $4^{\circ} \mathrm{C}$ for about 2-3 days, and the sediments were stored at $4^{\circ} \mathrm{C}$ before being used [10].

\subsection{Dark Fermentative Hydrogen Production}

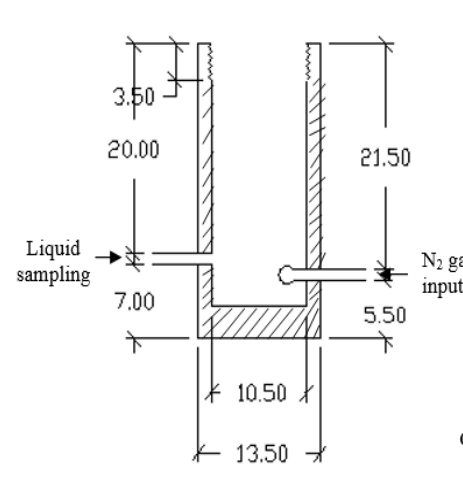

a) Reactor

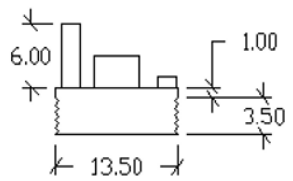

c) Front view of the cover

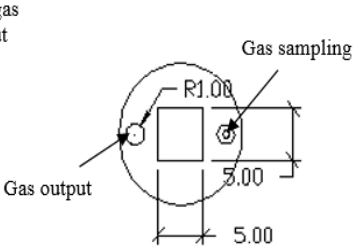

b) Top view of the cover a

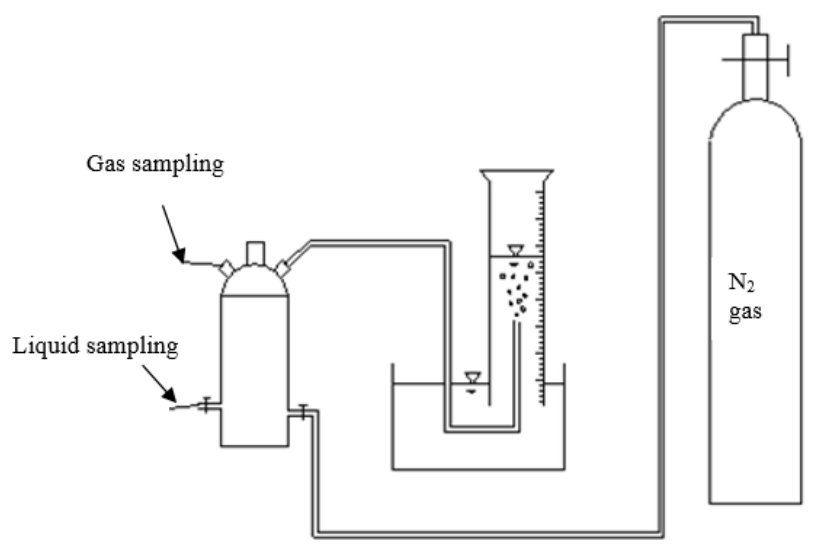

b
Figure 1. a. Reactor used in fermentation experiments; b. Experimental set-up

The sewage sludge was used as the substrate and the seed without addition of pure hydrogen producer for hydrogen production in the experiment. Experiments of biohydrogen production from sewage sludge by fermentation were carried out in a 2-liter bioreactor with a working volume of $750 \mathrm{~mL}$. Before the sludge samples were used to anaerobic fermentation, the $\mathrm{pH}$ value of sludge samples was adjusted to $4,5,6,7,8$ respectively by adding $2 \mathrm{M}$ hydrochloric acid $(\mathrm{HCl})$ or $4 \mathrm{M}$ sodium hydroxide $(\mathrm{NaOH})$. The $\mathrm{pH}$ adjusted sludge samples $(750 \mathrm{~mL})$ were added into 2-liter bioreactor, respectively. No extra nutrients were added into the tested sludge. The mixed culture seed microflora was obtained by acclimating wasted activated sludge from Municipal Sewage Treatment Plant in Samsun, Turkey. The bioreactor was equipped with two ports for gas and sludge sampling (Figure. 1a-1b). Before fermentation, the internal part of the reactor was purged with nitrogen gas for 3 minutes to provide anaerobic conditions. After quickly sealed, the reactor was placed into an incubator operating at $35^{\circ} \mathrm{C}$ and $150 \mathrm{rpm}$. In the whole process; $\mathrm{pH}, \mathrm{COD}$, protein and carbohydrate concentrations of the influent and the effluent with the hydrogen and methane concentration were monitored every day. The anaerobic digestion was continued until hydrogen production stopped or decreased.

\subsection{Analytical Methods}

During incubation, biogas production was measured periodically by displacement of saturated aqueous $10 \% \mathrm{NaCl}$ with $2 \% \mathrm{H}_{2} \mathrm{SO}_{4}$ in a graduated cylinder. The biogas in the headspace of digesters was sampled with a $1 \mathrm{~mL}$ gastight syringe. The hydrogen and methane contents of biogas were analyzed by a gas chromatograph (Shimadzu, GC-2010) equipped with a thermal conductivity detector (TCD) and $\mathrm{Rt}^{\mathbb{B}}$ - Msieve 5A (19723) capillary column. The temperatures of injector, detector and column were kept at $200^{\circ} \mathrm{C}, 200^{\circ} \mathrm{C}$ and $70^{\circ} \mathrm{C}$, respectively. Helium gas was used as the carrier gas with a flow rate of $19.3 \mathrm{~mL} \mathrm{~min}^{-1}$. The concentration of hydrogen and methane was tested frequently during fermentation and the biogas production was also recorded during the whole examination. The measured values were expressed as $\mathrm{mL} \mathrm{m}^{-3}(\mathrm{ppmv}=$ gas gas $^{-1}$ ). With the samples obtained at different times (before and after fermentation), characteristics of the sludge in the fermenter was identified.

The $\mathrm{pH}$ of sludge was measured by a $\mathrm{pH}$ meter (Sartorius PB-20). The TCOD and SCOD concentrations of sludge were determined with closed reflux titrimetric method according to the standard method [11]. Total and soluble proteins in the liquid phase were measured by the Lowry's method using bovine serum albumin as a standard solution [12], total and soluble carbohydrates by the phenol-sulfuric acid method using glucose as a standard solution [13]. The samples were filtered through a $0.45 \mu \mathrm{m}$ membrane and centrifuged at $4000 \mathrm{rpm}$ for $30 \mathrm{~min}$ before determining the concentrations of SCOD, S protein, and S carbohydrate.

\section{Results and Discussion}

\subsection{The Effect of $\mathrm{pH}$ on Biohydrogen Production of Sewage Sludge Dark Fermentation}

The data obtained from the experiments conducted at a temperature of $35^{\circ} \mathrm{C}$ and the $\mathrm{pH}$ ranging from 4 to 8 clearly demonstrated that biohydrogen production varies by the characterization of the sewage sludge. Following biohydrogen production via anaerobic fermentation, organics absorbed by the sewage sludge start dissolving. Since the degree of organic decomposition accelerates, solute concentrations also increase. Plenty of carbon sources were needed to maintain biological metabolism, so the 
anaerobic digestion speeded up, the organics was consumed by anaerobic bacteria as nutrient, and the organics started to decline. At the moment a large number of small bubbles attached to the conical flask because of biohydrogen bacterium starting to produce hydrogen [14]. This case observed along with the change in the gas volume.

As a result of the experiments conducted at a temperature of $35^{\circ} \mathrm{C}$ and $\mathrm{pH}$ ranging from 4 to 8 , hydrogen and methane concentrations which are read during fermentation are presented in Fig. 2 and Fig. 3, respectively. As seen in Fig. 2, the hydrogen production in the range of $\mathrm{pH}$ 4-8 first increased with time extension, and then decreased with further increase of fermentation time. It can also be seen from Fig. 2 that when the fermentation initial $\mathrm{pH}$ changed, the maximal hydrogen production varied. Maximum hydrogen production was realized within the first 24 hours. Except for one performed at $\mathrm{pH} 8$, hydrogen gas release was observed at other $\mathrm{pH}$ values within 2 hours. However, according to the results obtained at the 24th hour, maximum hydrogen production $\left(2489 \mathrm{~mL} / \mathrm{m}^{3} \mathrm{H}_{2}\right)$ was observed at $\mathrm{pH} 8$. With the increase in methane bacteria in the medium, hydrogen producing ability and hydrogen content of the sludge gradually decreased. When hydrogen production in the reactor decreased, hydrogen production period was ended. In general, hydrogen production after the 48 hours was less and in this study higher hydrogen production was obtained at $\mathrm{pH} 8$. Although in most literature, the production of hydrogen was conduction under acidic $\mathrm{pH}$ values [15-17], some researchers found higher $\mathrm{pH}$ could improve the hydrogen production and the volatile fatty acids $[6,18]$. Zhao et al. [6] performed their studies in a bottle (with 400 $\mathrm{mL}$ of the heat pretreated sludge each). They used sewage sludge as the substrate without addition of pure hydrogen producer and studied at $37 \pm 1^{\circ} \mathrm{C}$ at $120 \mathrm{rpm}$ and $\mathrm{pH} 4-11$. They reported that higher hydrogen production was obtained at higher $\mathrm{pH}$ (optimal at $\mathrm{pH} 11.0,70 \mathrm{~h}, 18.8 \mathrm{~mL} / \mathrm{gVS}$ or 13.5 $\mathrm{mL} / \mathrm{gCOD})$.

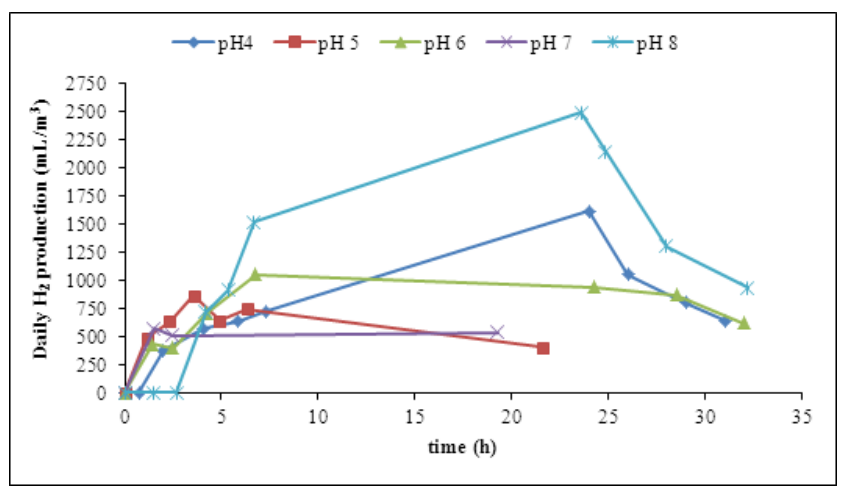

Figure 2. Hydrogen concentrations obtained at different $\mathrm{pH}$ values

Increase in methane concentration after the start of fermentation shows over reproduction of methanogenic bacteria in the medium (Figure. 3) which leads to hydrogen consumption. Therefore, hydrogen concentration in the gas phase shows fluctuations as shown in Figure. 2. In their studies, Cheng et al. [19] and Wang et al. [10] observed similar hydrogen consumption phase to that in our study during anaerobic fermentation [20]. Consumption of hydrogen by methane bacteria in the sludge an important barrier for hydrogen production from sludge and the main objective of all studies is to eliminate or delay this inhibitory factor.

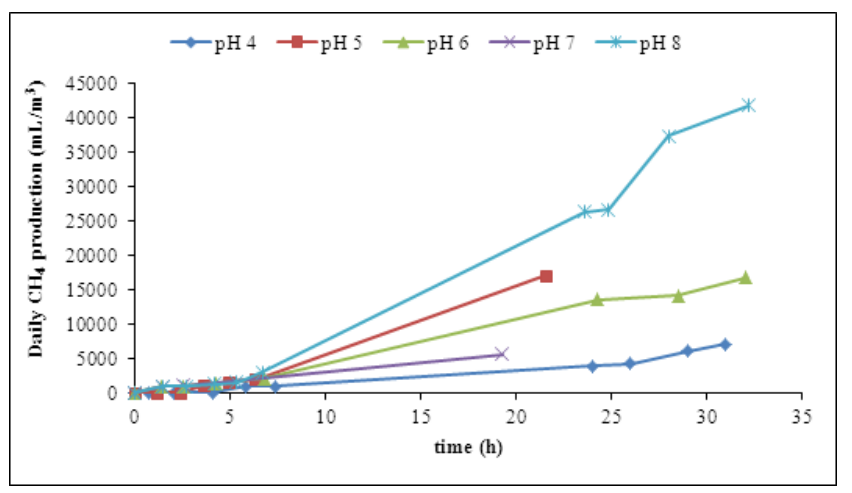

Figure 3. Methane concentrations obtained at different $\mathrm{pH}$ values

\subsection{Effect of pH on Solubilization of Sewage Sludge}

Figure 4 depicts the rate of chance in total protein, total carbohydrate and total chemical oxygen demand concentrations occurring in the reactor after fermentation experiments conducted at different $\mathrm{pHs}$ in waste sludge. Necessary analyses were performed for sewage sludge in the reactor before and after fermentation and the rate of change in the concentration was calculated.

Organic materials in the sludge, unlike glucose or sucrose, are mostly proteins. It was observed in the experiments that the amount of total protein changed with time. Therefore, as shown in Fig. 4, while protein consumption in the reactor adjusted to $\mathrm{pH} 4,6,7$ was founded; no consumption was observed at $\mathrm{pH} 5$ and 8 , in contrast, protein concentration probably increased due to hydrolysis. Increase in protein concentration due to hydrolysis also leads to increase in hydrogen gas concentration in the reactor adjusted to $\mathrm{pH} 8$.

When Figs. 2 and 4 are considered together, it was observed that there is a relationship between protein, carbohydrate and COD concentrations in the medium and hydrogen production. For the continuation of hydrogen production, as mentioned above, proteins and carbohydrates in the reactor should not be consumed by the microorganisms, in contrast, they should be increased via hydrolysis $[4,6-7,10,21]$. For hydrogen evolution, it is evident that nutritional needs of microorganisms should be constantly met. As it is seen, while the least protein, carbohydrate and COD consumption occur in the reactor adjusted to $\mathrm{pH} 8$ (Fig. 4), the highest hydrogen formation was also observed with the initial $\mathrm{pH}$ value of 8 (Fig. 2).

Sludge organic matters are mainly present in the particle form. During sludge fermentation for biohydrogen production, these organic materials usually undergo solubilization, hydrolysis and acidification. The changes of soluble protein and carbohydrate were applied in the current 
study to express the solubilization of sludge main particulate organic matters. As shown in Figure. 5. The solubilization of protein and carbohydrate in sludge changed significantly with $\mathrm{pH}$.

Two mechanisms can be successful in increasing the efficiency of anaerobic fermentation: i) reduction in the competitive microbial load and ii) increase in the organic availability [22]. As it is seen in Fig. 5 and Table 2, solubility of all organic matters in sewage sludge was higher in $\mathrm{pH} 6$ at $35^{\circ} \mathrm{C}$ in comparison to the experiments conducted at different pHs. At $\mathrm{pH} 6$, after fermentation, the amount of dissolved COD, carbohydrate and protein increased much more than that in other $\mathrm{pH}$ experiments. At the same time, SCOD/TCOD (\%) and Scarbohydrate/Tcarbohydrate (\%) ratios in analyses of sewage sludge obtained from the reactor after fermentation also confirms this result.

Studies conducted in the literature have shown that the increase in the amount of dissolved COD, carbohydrates and protein positively affects hydrogen production. However, as mentioned above, having dissolved organic matter that can be easily used by the microorganisms in the environment is not the only parameter affecting the efficiency of hydrogen which results from the fermentation. Microbial species in sewage sludge are also very important for the biological way of hydrogen production. Therefore, although the reactor adjusted to $\mathrm{pH} 6$ seems to be more suitable for hydrogen production in terms of total and soluble matter concentration, the amount of hydrogen obtained in the reactor with the initial $\mathrm{pH}$ of 8 is higher.

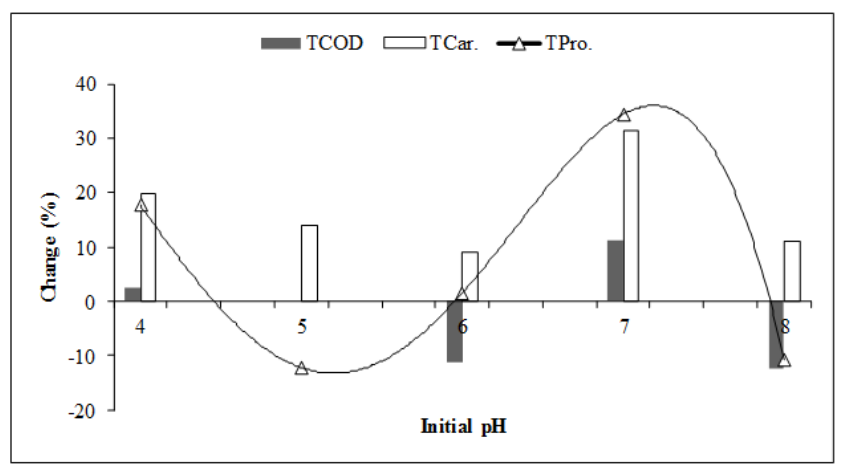

Figure 4. The change in the total matter concentration at the end of fermentation

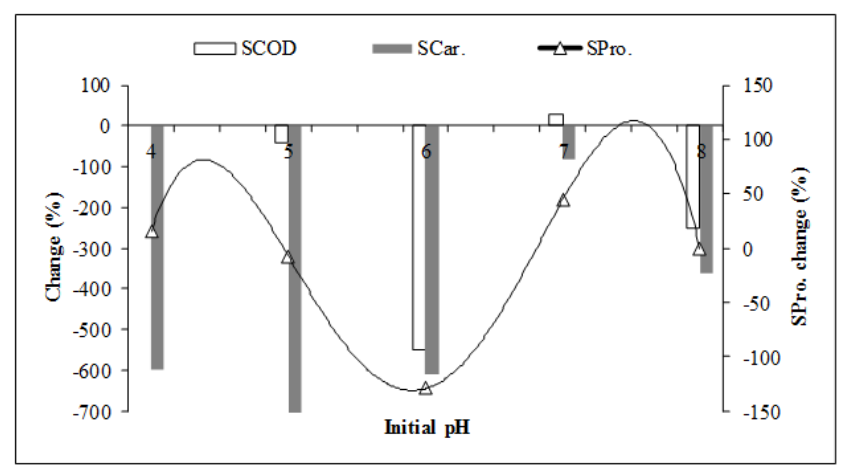

Figure 5. The change in the soluble matter concentration at the end of fermentation
Table 2. SCOD / TCOD and Scarbohydrate / Tcarbohydrate (\%) in the mixture liquid before fermentation (I) and after fermentation (II)

\begin{tabular}{ccccc}
\hline $\begin{array}{c}\text { Initial } \\
\mathbf{p H}\end{array}$ & $\begin{array}{c}\mathbf{I} \\
\text { SCOD/ } \\
\text { TCOD (\%) }\end{array}$ & $\begin{array}{c}\text { II } \\
\text { SCOD/ } \\
\text { TCOD (\%) }\end{array}$ & $\begin{array}{c}\text { I } \\
\text { SCar./ } \\
\text { TCar. (\%) }\end{array}$ & $\begin{array}{c}\text { II } \\
\text { SCar./ } \\
\text { TCar. (\%) }\end{array}$ \\
\hline 4 & 0.44 & 0.46 & 0.24 & 2.07 \\
5 & 0.44 & 0.62 & 0.20 & 2.49 \\
6 & 0.44 & 2.60 & 0.38 & 2.98 \\
7 & 0.36 & 1.00 & 0.66 & 1.74 \\
8 & 0.53 & 1.64 & 0.43 & 2.23 \\
\hline
\end{tabular}

\section{Conclusions}

The experimental investigation indicated that wastewater sewage sludge was preferred as a raw material for biohydrogen production via anaerobic fermentation. Total and dissolved substances are used to meet the nutritional needs of microorganisms in the fermenter and consequently this also increases its hydrogen production efficiency. Especially, increase the amount of total and soluble substance positively affected hydrogen production within the first 24 hours.

Another important factor affecting hydrogen production is SCOD/TCOD ratio. However, this increase is not directly proportional. In this study, solubility was higher at pH 6 in comparison to other $\mathrm{pH}$ values. Despite that, hydrogen production at $\mathrm{pH} 8$ was higher due to microbial activity in sewage sludge.

In the experiments performed at different $\mathrm{pH}$ values at $35^{\circ} \mathrm{C}$, maximum hydrogen production was achieved within the first 24 hours. Except for one performed at $\mathrm{pH} 8$, hydrogen gas release was observed at other $\mathrm{pH}$ values within 2 hours. However, according to the results obtained at the 24th hour, maximum hydrogen production $\left(2489 \mathrm{~mL} / \mathrm{m}^{3} \mathrm{H}_{2}\right)$ was observed at $\mathrm{pH} 8$. With the increase in methane bacteria in the medium, hydrogen producing ability and hydrogen content of the sludge gradually decreased. In general, hydrogen production after the second day was less. In addition, there was observed a relationship between protein, carbohydrates and chemical oxygen demand concentration in the medium and hydrogen production.

\section{Acknowledgments}

The authors thank Ondokuz Mayis University, Scientific Research Project Funding (OMU BAP) for their financial support [Project number: PYO.MUH.1904.12.006].

\section{REFERENCES}

[1] M. L. Cai, J. X. Liu, Y. S. Wei. Enhanced biohydrogen production from sewage sludge with alkaline pretreatment, Environmental Science \& Technology, Vol.38, No.11, 3195-3202, 2004. 
[2] L. Guo, X.-M. Li, G.-M. Zeng, Y. Zhou. Effective hydrogen production using waste sludge and its filtrate, Energy, Vol.35, No.9, 3557-3562, 2010.

[3] Q. Liu, X. Zhang, L. Yu, A. Zhao, J. Tai, J. Liu, G. Qian, Z. $\mathrm{P}$. Xu. Fermentative hydrogen production from fresh leachate in batch and continuous bioreactors, Bioresource Technology, Vol. 102, No. 9, 5411-5417, 2011.

[4] L. Guo, X.-M. Li, X. Bo, Q. Yang, G.M. Zeng, D. Liao, J. J. Liu. Impacts of sterilization, microwave and ultrasonication pretreatment on hydrogen producing using waste sludge, Bioresource Technology, Vol. 99, No. 9, 3651-3658, 2008.

[5] I. Senturk, H. Buyukgungor. An examination of used different waste materials and biohydrogen production methods, Sigma Journal of Engineering and Natural Sciences, Vol.28, No.4, 369-395, 2010.

[6] Y. Zhao, X. Liang, H. Mu, X. Zhang. Biohydrogen production from sewage sludge by sequential dark and photo fermentation, Journal of Biobased Materials and Bioenergy, Vol.9, No.1, 95-100, 2015.

[7] M. Nicolau, J. R. Dinsdale, A. Guwy. Hydrogen production from sewage sludge using mixed microflora inoculum: Effect of $\mathrm{pH}$ and enzymatic pretreatment, Bioresource Technology, Vol. 99, No. 14, 6325-6331, 2008.

[8] S. H. Kotay, D. Das. Microbial hydrogen production from sewage sludge bioaugmented with a constructed microbial consortium, The International Journal of Hydrogen Energy, Vol.35, No.19, 10653-10659, 2010.

[9] B. Xiao, J. Liu. Biological hydrogen production from sterilized sewage sludge by anaerobic self-fermentation, The Journal of Hazardous Materials, Vol.168, No.1, 163-167, 2009.

[10] C. C. Wang, C. W. Chang, C. P. Chu, D. J. Lee, B. Chang, C. S. Liao. Producing hydrogen from wastewater sludge by Clostridum bifermentans, Journal of Biotechnology, Vol.102, No.1, 83-92, 2003.

[11] APHA. Standard methods for the examination of water and wastewater. 20th ed. Washington, D. C.: American Public Health Association; 2005.

[12] O. H. Lowry, N. J., Rosebrough, A. L., Farr. et al. Protein measurement with the Folin phenol reagent, Journal of Biological Chemistry, Vol.193, No.1, 265-275, 1951.

[13] M. Dubois, K. A., Gilles, J. K., Hamilton, P. A., Rebers, F. Smith. Colorimetric method for determination of sugars and related substances, Analytical Chemistry, Vol.28, No.3, 350-356, 1956.

[14] F. Wu, S. Q. Zhou, Y. L. Lai, W. J. Zhong. Studies on the effects of pretreatment on production hydrogen from municipal sludge anaerobic fermentation, National Academy of Sciences, Vol.1, No.1, 10-16, 2009.

[15] T. Y. Jeong, G. C. Cha, I. K. Yoo, D. J. Kim. Hydrogen production from waste activated sludge by using separation membrane acid fermentation reactor and photosynthetic reactor, The International Journal of Hydrogen Energy, Vol.32, No.5, 525-530, 2007.

[16] C. C. Wang, C. W. Chang, C. P. Chu, D. J. Lee, B. V. Chang, C. S. Liao, J. H. Tay. Using filtrate of waste biosolids to effectively produce bio-hydrogen by anaerobic fermentation, Water Resource, Vol.37, No.11, 2789-2793, 2003.

[17] C. H. Ting, D. J. Lee. Production of hydrogen and methane from wastewater sludge using anaerobic fermentation, The International Journal of Hydrogen Energy, Vol.32, No.6, 677-682, 2007.

[18] M. Cai, J. Liuand, Y. Wei. Enhanced biohydrogen production from sewage sludge with alkaline pretreatment, Environmental Science \& Technology, Vol.38, No.11, 3195-3202, 2004.

[19] S. S. Cheng, M. D. Bai, S. M. Chang, K. L. Wu, W. C. Chen. Studies on the feasibility of hydrogen production hydrolyzed sludge by anaerobic microorganisms, The Twenty-fifth Wastewater Technology Conference, Yunlin, Taiwan (in Chinese), 2000.

[20] C. C. Wang, C. W. Chang, C. P. Chu, D. J. Lee, B. V. Chang, C. S. Liao. Hydrogen production from wastewater sludge using a Clostridium strain, Journal of Environmental Science and Health. Part A, Toxic/Hazardous Substances \& Environmental Engineering, Vol.A38, No.9, 1867-1875, 2003b.

[21] G. Ozsoy, F. B. Dilek, F. D. Sanin. An investigation of agricultural use potential of wastewater sludges in Turkey--case of heavy metals, Water Science and Technology, Vol.54, No.5, 155-161, 2006.

[22] S. M. Kotay, D. Das. Novel dark fermentation involving bioaugmentation with constructed bacterial consortium for enhanced biohydrogen production from pretreated sewage sludge, The International Journal of Hydrogen Energy, Vol.34, No.17, 7489-7496, 2009. 